\title{
Influence of cold-dry (harmattan) season on colonic temperature and the development of pulmonary hypertension in broiler chickens, and the modulating effect of ascorbic acid
}

\author{
This article was published in the following Dove Press journal: \\ Open Access Animal Physiology \\ 10 March 2014 \\ Number of times this article has been viewed
}

\author{
Ndazo S Minka' \\ Joseph O Ayo ${ }^{2}$ \\ 'Department of Animal Health and \\ Husbandry, College of Agriculture \\ and Animal Science, Division of \\ Agricultural Colleges, Ahmadu Bello \\ University, Mando-Kaduna, Nigeria; \\ ${ }^{2}$ Department of Physiology, Faculty of \\ Veterinary Medicine, Ahmadu Bello \\ University, Zaria, Nigeria
}

\begin{abstract}
The influence of cold-dry (harmattan) season on colonic temperature (CT) and the development of pulmonary hypertension (PH), as well as the effect of ascorbic acid (AA), were investigated in Anak male broilers during the harmattan season (November-January) of 2010-2013. A total of 150 broiler chickens per season served as subjects. At the age of 4 weeks, the broilers were randomly divided into two groups consisting of three replicates of 25 birds each: group I, the control, was not administered AA; group II was AA-treated, administered with $200 \mathrm{mg} / \mathrm{kg}$ body weight of AA, every day at $7 \mathrm{am}$ and $7 \mathrm{pm}$ for a period of 3 weeks. The mortality rate and $\mathrm{CT}$ of the birds were recorded during the daytime and nighttime. Ten birds from each group were sacrificed at weeks 4, 5, 6, and 7 for the assessment of $\mathrm{PH}$ and ascites syndromes. The mean ambient temperature value of $24.3^{\circ} \mathrm{C} \pm 0.1^{\circ} \mathrm{C}$ recorded in the daytime was higher $(P<0.05)$ than the value of $17.2^{\circ} \mathrm{C} \pm 0.1^{\circ} \mathrm{C}$ recorded during the nighttime. The average level of dust was $8.2 \mathrm{mg} / \mathrm{m}^{3}$. The control birds were hypothermic during the nighttime and had high mortality rates compared with the AA-treated birds. Broilers with obvious signs of ascites demonstrated a uniquely continuous increase in CT. At weeks 6 and 7 of age, $80 \%$ of the control broilers that were sacrificed exhibited an increase $(P<0.05)$ in the weight of right ventricle to the weight of total ventricles, packed cell volume, and erythrocyte count with low hemoglobin content, which indicated PH syndrome. The remaining $20 \%$ of the control birds and those that died had ascites syndrome in addition to the PH syndrome. These syndromes were not observed in the AA-treated birds. In conclusion, the harmattan season induced $\mathrm{PH}$ in broilers with no obvious clinical signs; the harmattan may compromise the welfare, health, productivity, and meat quality of the birds, effects which were ameliorated by AA.
\end{abstract}

Keywords: ascorbic acid, broilers, cold-dry (harmattan), colonic temperature, hypothermia, pulmonary hypertension/ascites

\section{Introduction}

The harmattan season occurs from November to early March in the Gulf of Guinea. It is characterized by a very cold-dry $\left(9^{\circ} \mathrm{C}\right)$ and dust-laden wind, blowing northeast and west off the Sahara desert into the Gulf of Guinea, towards the Caribbean and South America. ${ }^{1,2}$ The harmattan season differs from winter because it is characterized by cold-dry wind, heavy dust-laden particles, and wide fluctuations in day and night ambient temperatures (AT). The harmattan wind is considered a natural hazard because during its passage over the desert it picks up fine dust particles and can push large quantities of sand and dust, facilitating the spread of wind-borne diseases for
Correspondence: Ndazo S Minka I6b Muazu Lamido Street, Department of Animal Health and Husbandry, College of Agriculture and Animal Science, PMB 2134, Division of Agricultural Colleges, Ahmadu Bello University, Mando-Kaduna, Nigeria Tel +234803652753

Emailmnsalka@yahoo.com 
thousands of kilometers. ${ }^{3}$ In spite of the deleterious effects of the harmattan season on humans and its wide coverage through the Sahara desert into the Gulf of Guinea (Figure 1), there are limited studies on the impact of the season on livestock (especially poultry) ${ }^{4}$ when compared to the volume of studies conducted on the effect of hot-dry season or heat stress on poultry. ${ }^{5-7}$

Broiler chickens are prone to severe pulmonary hypertension (PH); several studies have shown that other factors such as high growth rate, genetics, rearing conditions, poor management, cold stress, and high levels of dust particles are implicated in the pathology of $\mathrm{PH} .{ }^{8-12}$ Birds suffering from PH have been reported to have depressed respiratory capacity, changes in heart morphology (right ventricle weight to total ventricle weight [RV/TV] ratio), fluid accumulation, stunted growth and increased mortality, packed cell volume (PCV), hemoglobin $(\mathrm{Hb})$ concentration, and red blood cell (RBC) counts. ${ }^{8,13,14}$ The parameters are often used to diagnose ascites in broilers. Body temperature in birds, measured as colonic temperature (CT), has been used to measure the level of stress and adaptability of animals to various stress conditions. ${ }^{4,7}$ To date, there is paucity of information in the available literature on the effect of the harmattan season on the development of PH in broilers. Preliminary investigation has shown that mortality rates in chickens was very high during the harmattan season as compared to other seasons of the year. ${ }^{15}$ Although macroclimatic conditions during the harmattan season in the tropics cannot be controlled easily, adequate and effective prophylactic measures may reduce the adverse effects of cold and dust on birds during the season. Such measures will reduce costs and improve the efficiency of poultry production in areas exposed to the harmattan wind.

Many nutritional, medicinal, and management strategies have been proposed to alleviate incidence of $\mathrm{PH}$ due to multiple stress factors. ${ }^{13,16,17}$ However, the effects of the agents in ameliorating $\mathrm{PH}$ in broilers reared during the harmattan season have not been investigated; additionally, diagnoses of animal diseases are generally done during the daytime, ignoring the possible adverse effects of nighttime environmental conditions. There is an increasing body of evidence supporting the use of ascorbic acid (AA) as an antistress, particularly against the development of $\mathrm{PH}$ in birds. . $^{4,8,13}$

The aims of the present study were to investigate the effects of daytime and nighttime harmattan on CT and the development of $\mathrm{PH}$ in broilers, as well as the ameliorating effect of AA.

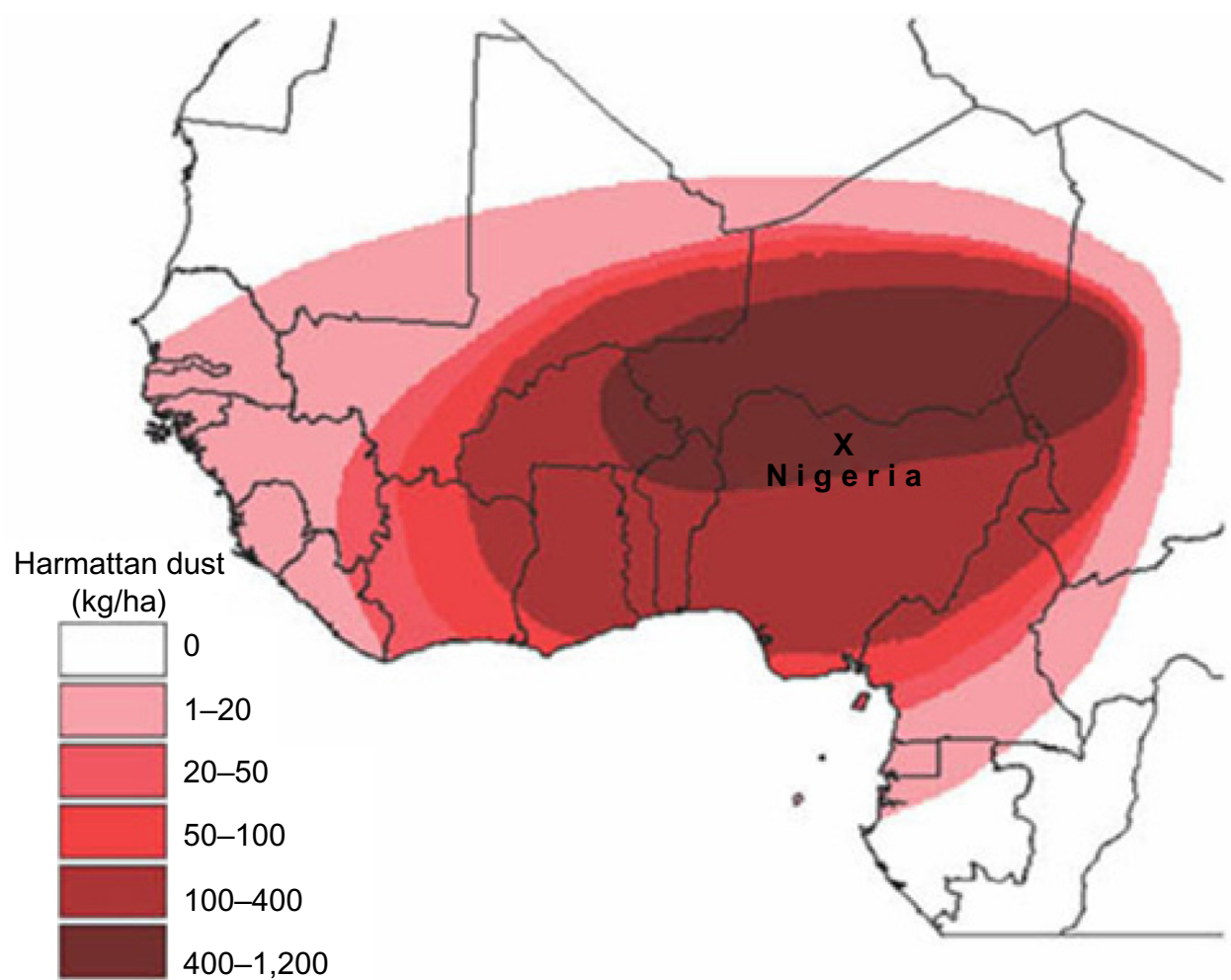

Figure I Distribution of harmattan dust particles in Africa.

Note: X represents the location of Kaduna town, Nigeria. Copyright @ Academic Journals. Reprinted with permission from Oladele AO. Harmattan haze and environmental health. Afr J Environ Sci Technol. 2007; I (4): I-3. ${ }^{3}$ 


\section{Materials and methods \\ Experimental site and environmental variables}

The experiment was conducted during the harmattan seasons of 2010-2013 (from November 15 to January 10) at the Livestock Farm of the College of Agriculture and Animal Science, Mando-Kaduna $\left(11^{\circ} 10^{\prime} \mathrm{N}, 07^{\circ} 38^{\prime} \mathrm{E}\right)$, located in the Northern Guinea Savannah zone of Nigeria. The AT and relative humidity $(\mathrm{RH})$ were recorded during the daytime and nighttime at 2-hour intervals with the aid of a dry- and wetbulb thermometer (DTH 1; Clarke International Ltd, Essex, UK), three times per week during the study periods.

\section{CT}

The body temperature (measured as CT) of the birds was recorded at $6 \mathrm{am}, 10 \mathrm{am}, 2 \mathrm{pm}, 6 \mathrm{pm}, 10 \mathrm{pm}$, and 4 am using a digital clinical thermometer (The Hartman Group, Heidenheim, Germany); the thermometer was inserted about 4-5 cm into the rectum through the cloaca and left until an alarm sound was heard, indicating the end of the reading. The CT was recorded during the 4th, 5th, 6th, and 7th week of the broilers' life. Individual birds with CT above normal values during both the daytime and nighttime were specifically color-marked for further assessment of abdominal fluid accumulation.

\section{Birds' management and experimental design}

A description of the experimental protocol used during the study period of the harmattan season from 2010-2013 is shown in Table 1. During the study period, from November 15, 2010 to January 10, 2013, 200 Anak strain of broilers were obtained per season and yearly as day-old chicks from Success Golden Chicks Farm, Ibadan $\left(07^{\circ} 23^{\prime} \mathrm{N}\right.$, $\left.03^{\circ} 52^{\prime} \mathrm{E}\right)$, Nigeria, and were brooded in a standard poultry pen until 4 weeks of age. All birds were reared in floor pens on fresh wood shavings for 4 weeks. From day-old to 28 days, all chicks were kept under a 23-hour light regime and were given access to clean drinking water and standard commercial broiler chick ration ad libitum. The birds were brooded at $32^{\circ} \mathrm{C}, 30^{\circ} \mathrm{C}, 28^{\circ} \mathrm{C}$, and $24^{\circ} \mathrm{C}$ during weeks $1,2,3$, and 4 , respectively; thereafter, they were maintained at $21^{\circ} \mathrm{C}-24^{\circ} \mathrm{C}$ during weeks 5,6 , and 7 . From weeks 5-7 the birds were given access to clean water and standard broilers' mash ad libitum. The crude protein and energy levels for the broilers at $0-28$ days-old were $23.1 \%$ and $13.44 \mathrm{MJ}$ $\mathrm{ME} \mathrm{kg}^{-1}$, respectively; at 5-7 weeks, the corresponding

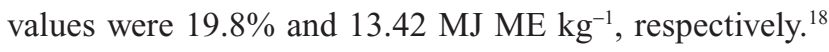

Table I Description of experimental protocol during the study period of the harmattan season from 2010-2013

\begin{tabular}{|c|c|}
\hline Activities & Period \\
\hline Year of study & 2010 to 2013 \\
\hline Months of study & I5th November to I0th January \\
\hline Brooding period & $\begin{array}{l}\text { I } 5 \text { th November to I5th December } \\
\text { (4 weeks) }\end{array}$ \\
\hline $\begin{array}{l}\text { Assignment of birds to } \\
\text { experimental groups }\end{array}$ & I5th December (at 4 weeks of age) \\
\hline $\begin{array}{l}\text { Administration of ascorbic } \\
\text { acid to birds }\end{array}$ & $\begin{array}{l}\text { From the } 4 \text { th to the } 7 \text { th week of age } \\
\text { (at } 7 \text { am and } 7 \text { pm daily) }\end{array}$ \\
\hline $\begin{array}{l}\text { Colonic temperature } \\
\text { measurements }\end{array}$ & $\begin{array}{l}\text { From the } 4 \text { th to the } 7 \text { th week of age } \\
\text { (at } 6 \mathrm{am}, 10 \mathrm{am}, 2 \mathrm{pm}, 6 \mathrm{pm}, 10 \mathrm{pm} \\
\text { and } 4 \mathrm{am} \text { daily, at day and night) }\end{array}$ \\
\hline Body weight measurements & Weekly from the 4 th to the 7 th week \\
\hline $\begin{array}{l}\text { Sacrifice, blood sampling, } \\
\text { and pulmonary hypertension } \\
\text { measurements }\end{array}$ & Weekly from the 5 th to the 7 th week \\
\hline Sampling of harmattan dust & $\begin{array}{l}\text { Three times weekly from the } 4 \text { th to } \\
\text { the } 7 \text { th week }\end{array}$ \\
\hline
\end{tabular}

The birds were stocked at 10 broilers $/ \mathrm{m}^{2}$. The AT inside the pen post-brooding (week 5 to 7) was, however, influenced by the effects of the daytime and nighttime harmattan wind. The wood shavings were kept clean throughout the study period. Management of the broilers, including recommended vaccinations against common infectious diseases, strictly adhered to the standard routine. Out of the 200 birds stocked per season, 150 male broilers were selected as subjects for each study season. At 4-weeks old, the broilers were randomly divided into AA-treated and control groups, comprising 75 birds per group with three replicates of 25 birds each. The AA-treated broilers were administered orally and individually with $200 \mathrm{mg} / \mathrm{kg}$ body weight of AA, dissolved in $3 \mathrm{~mL}$ of sterile water, twice daily $(400 \mathrm{mg})$ at $7 \mathrm{am}$ and $7 \mathrm{pm}$ for a period of 3 weeks. At the same time, the control group was given equivalent of sterile water. The dosage of AA used in the present study has been proven to mitigate oxidative stress caused by intermittent cold exposure. ${ }^{19}$ The AA and sterile water were given to each bird using a gavage by gentle feeding through the beak with minimal stress. ${ }^{20} \mathrm{Ten}$ birds selected at random from each group were sacrificed at weeks 5, 6, and 7 (Table 1), and the heart of each bird was carefully removed for analyses of PH. During the evaluation, noticeable abdominal and pericardial fluid contents and liver abnormalities were scored. Every week, just before sacrifice at $6.30 \mathrm{am}$, the body weight of each bird was recorded, and at the same time a blood sample was obtained from the wing vein of the bird for additional analysis of $\mathrm{PH}$ indicators, which included PCV, $\mathrm{Hb}$ concentration, $\mathrm{Hb}$ index and erythrocyte count. ${ }^{21-23}$ 


\section{Assessment of $\mathrm{PH}$ and mortality}

\section{Blood samples}

About $5 \mathrm{~mL}$ of blood sample was collected from the wing vein of the broilers just before sacrifice in heparinized tubes; samples were analyzed within 1-2 hours of collection, for $\mathrm{PCV}, \mathrm{Hb}$ concentration, and RBC count using an automated cell counter (Celltac MEK-6108 K; Nihon-Kohdon, Tokyo, Japan). The hemoglobin index (HI), which is the quantity of $\mathrm{Hb}$ attached to individual $\mathrm{RBC}$, was assessed as follows: $:^{21,24}$ $\mathrm{HI}=$ obtained $\mathrm{Hb} \times$ average $\mathrm{RBC} /$ average $\mathrm{Hb} \times$ obtained $\mathrm{RBC}$. If $\mathrm{Hb}$ index $=1$, the erythrocytes are normal (normochromic); if $<1$, they are hypochromic; and if $>1$, they are hyperchromic.

\section{Heart, abdomen, and liver}

The PH was assessed by the ratio of the weight of right ventricle (RV) to the weight of total ventricle (TV) as described by Wideman ${ }^{25}$ and Zamani Moghaddam et al. ${ }^{13}$ Briefly, after sacrifice at the 5th, 6th, and 7th week of life, the heart of each bird was removed and the left and right atria were dissected from the ventricles. The two ventricles were first weighed (Digital Pricing Scale with LED/LCD Display (400N); Xiamen Merc Electronic Technology Co., Ltd., Fujian, People's Republic of China), after which the RV was carefully separated from the left and weighed. The ratio of the RV over the TV was calculated as PH index (that is, $\mathrm{RV} / \mathrm{TV}=\mathrm{PH}$ index). A ratio of $0.24-0.28$ was considered normal. ${ }^{25,26}$ Birds having a RV/TV ratio $\geq 0.278$ to $<0.299$ were classified as suffering from right ventricular failure and indicative of the presence of PH. ${ }^{13,27,28}$

Additionally, birds that died with ascites or those that died with obvious pre-PH symptoms were included in the total $\mathrm{PH}$ mortality. ${ }^{28}$ All dead birds were examined for the presence of typical lesions of ascites; accumulation of fluid in the heart sac was scored 0 if there was no fluid, 1 if there was some fluid accumulation, and 2 if there was serious accumulation of fluid. Liver abnormalities were scored as 0 if there were no abnormalities observed, 1 if there was an abnormal liver, and 2 if there were serious liver abnormalities. Liver abnormalities included a lighter color, an irregular liver surface, or both. The accumulation of fluid in the abdomen was scored as 0 if there was no fluid, 1 if there was some fluid, and 2 if there was a serious accumulation of fluid. ${ }^{10,29}$

\section{Sampling of harmattan dust}

The harmattan dust inside the poultry house was sampled at three different spots during both day and night, three times per week, from the December 15, 2010 to January 10,
2013 (Table 1). The sampling of dust particles was done on Whatman filter paper (Whatman International Ltd, Maidstone, UK) as described by Vucemilo et al. ${ }^{30}$ The filter paper was weighed before and immediately after each period of sampling. The difference in the weights was taken as the quantity of dust.

\section{Statistical analysis}

Data were analyzed using two-way analysis of variance (ANOVA) with repeated measures. ANOVA was followed by post hoc Fisher's Least Significant Difference test. Mortality data were analyzed using a chi-square test. All statistical analyses were performed using Statistical 7.0 statistical software (StatSoft Inc, Tulsa, OK USA). The overall level of statistical significance was defined as $P<0.05$.

\section{Results}

\section{Thermal environmental variables}

The hourly fluctuations in thermal environmental variables and $\mathrm{CT}$ of the broilers recorded during the study period are shown in Figure 2A-C. The AT inside the pen during the daytime had mean, maximum, and minimum values of $24.3^{\circ} \mathrm{C} \pm 0.1^{\circ} \mathrm{C}$, $28.5^{\circ} \mathrm{C}$, and $17.0^{\circ} \mathrm{C}$, respectively; the corresponding respective values of $17.2^{\circ} \mathrm{C} \pm 0.1^{\circ} \mathrm{C}, 19.5^{\circ} \mathrm{C}$, and $15.5^{\circ} \mathrm{C}$ were recorded during the nighttime. Outside the pen, the AT recorded during the daytime had mean, maximum, and minimum values of $23.3^{\circ} \mathrm{C} \pm 0.3^{\circ} \mathrm{C}, 31.2^{\circ} \mathrm{C}$, and $16.7^{\circ} \mathrm{C}$, respectively; corresponding respective values of $14.0^{\circ} \mathrm{C} \pm 0.2^{\circ} \mathrm{C}, 18.6^{\circ} \mathrm{C}$, and $9.8^{\circ} \mathrm{C}$ were obtained during the nighttime (Figure $2 \mathrm{~A}$ ). The $\mathrm{RH}$ values recorded in both the daytime and nighttime inside and outside the pen during the study period fluctuated between $18.5 \%$ and $25.0 \%$ (Figure 2B).

\section{CT of the birds}

There were no significant differences in the $\mathrm{CT}$ values of the broilers at 4 weeks of age before the administration of AA, although individual birds exhibited variations in the CT values. The CT significantly $(P<0.05)$ increased during the day and decreased during the nighttime period (Table 2). During the period of AA administration, the CT values recorded in the control broilers during the daytime at weeks 5,6 , and 7 had mean values of $42.3^{\circ} \mathrm{C} \pm 0.5^{\circ} \mathrm{C}$, $42.8^{\circ} \mathrm{C} \pm 0.2^{\circ} \mathrm{C}$, and $43.1^{\circ} \mathrm{C} \pm 0.7^{\circ} \mathrm{C}$, respectively, which were significantly $(P<0.05)$ higher than the corresponding values of $41.4^{\circ} \mathrm{C} \pm 0.3^{\circ} \mathrm{C}, 42.0^{\circ} \mathrm{C} \pm 0.4^{\circ} \mathrm{C}$, and $41.8^{\circ} \mathrm{C} \pm 0.2^{\circ} \mathrm{C}$, respectively, recorded in AA-treated broilers. During the nighttime period, the mean $\mathrm{CT}$ value of $39.3^{\circ} \mathrm{C} \pm 0.7^{\circ} \mathrm{C}$, obtained in control broilers at weeks 5 and 6 , respectively, was lower 


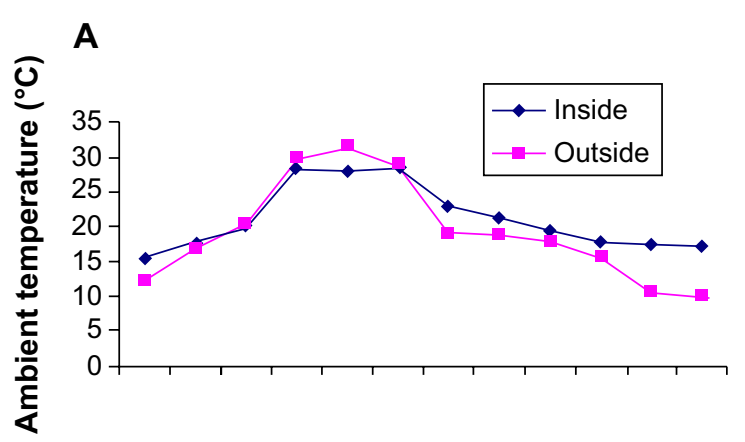

B

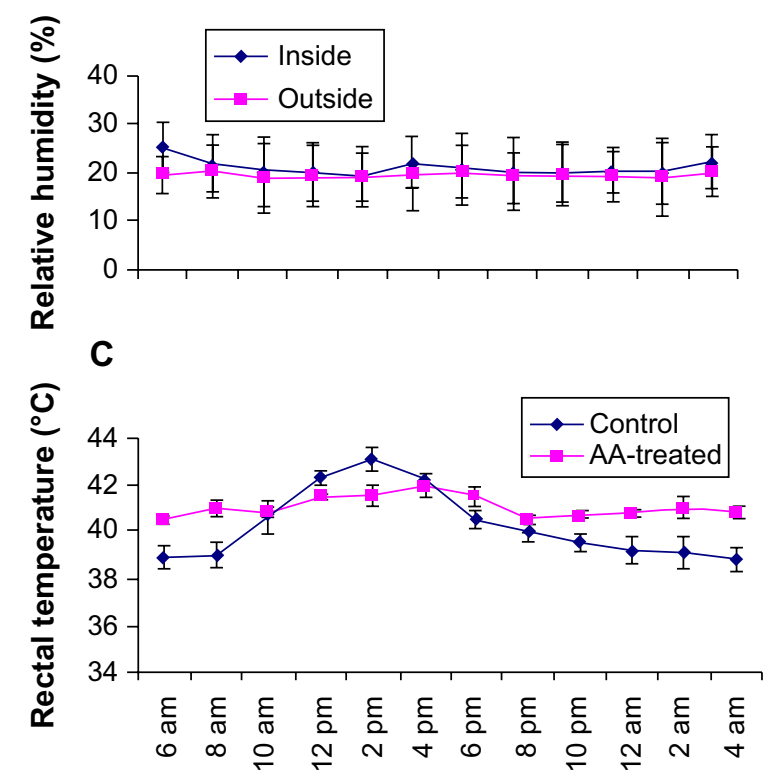

Time

Figure 2 Overall fluctuations in AT and RH and the effect of AA on hourly fluctuations on $\mathrm{CT}$ of birds during study period.

Notes: Overall fluctuations in (A) AT and (B) RH; (C) the effect of AA on hourly fluctuations in $C T$ of the control $(n=75)$ and AA-treated $(n=75)$ broilers during the harmattan periods of 2010-2013.

Abbreviations: AT, ambient temperature; $\mathrm{RH}$, relative humidity; AA, ascorbic acid; CT, colonic temperature.

$(P<0.001)$ than that recorded at week $7\left(42.8^{\circ} \mathrm{C} \pm 0.5^{\circ} \mathrm{C}\right)$. In AA-treated broilers, the mean $\mathrm{CT}$ values recorded during the daytime and nighttime period were within the range values of $40^{\circ} \mathrm{C}-42^{\circ} \mathrm{C}$. Birds with obvious clinical signs of ascites had CT values that were consistently above $42.5^{\circ} \mathrm{C}$ during both the daytime and nighttime.

\section{$\mathrm{PH}$ ratio and mortality}

The RV/TV ratio recorded in ten 4-week-old birds before the administration of AA had mean, maximum, and minimum values of $0.178 \pm 0.05,0.189$, and 0.160 , respectively. After the administration of AA at the 5th, 6th and 7th week of life, the control birds had RV/TV ratios of $0.233 \pm 0.05$, $0.301 \pm 0.02$, and $0.315 \pm 0.04$, respectively, which were significantly $(P<0.05)$ higher than the corresponding $\mathrm{RV} / \mathrm{TV}$ ratios of $0.178 \pm 0.01,0.205 \pm 0.05$, and $0.210 \pm 0.04$, respectively, recorded in the AA-treated birds (Figure 3). The $\mathrm{RV} / \mathrm{TV}$ ratio of 0.28 and above signifies the development of PH. Only $20 \%$ of the broilers in control birds with clinically significant heart pathology (RV/TV ratio above 0.28 ) fully developed ascites syndrome at week 7 , which included excess accumulation of abdominal and pericardial fluid and liver abnormalities.

A mortality rate of $25.3 \%$ was recorded in control broilers from the 5 th to the 7 th week of life, whereas a $5.3 \%$ mortality was recorded in AA-treated birds. The mortality rate was higher $(P<0.05)$ at the 7 th week of life, with the values of $14.7 \%$ and $4.0 \%$ for control and AA-treated birds, respectively (Figure 4). Postmortem results obtained immediately after death revealed serious liver abnormalities (score of 2 on a 2-point scale) and excessive fluid accumulation (score of 2 on a 2-point scale) in the abdominal and pericardial cavities in $80 \%$ of control broilers that had died.

\section{Feed consumption, liveweight and dust concentration}

The average weekly feed intake of $0.878 \pm 0.02 \mathrm{~kg} / \mathrm{bird}$ recorded in AA-treated broilers was higher $(P<0.05)$ than the $0.728 \pm 0.01 \mathrm{~kg} / \mathrm{bird}$ recorded in control birds. The respective liveweights of the control and AA-treated broilers were only different $(P<0.05)$ at the 6 th and 7 th week of life. The AAtreated broilers had a final average liveweight of $2.230 \pm 0.05$ $\mathrm{kg} /$ bird, which was higher $(P<0.05)$ than the average value of $1.978 \pm 0.04 \mathrm{~kg} / \mathrm{bird}$ recorded in the control birds. The dust concentration in each season per year fluctuated from 5.2 to $11.5 \mathrm{mg} / \mathrm{m}^{3}$, with a mean concentration of $8.2 \pm 0.3 \mathrm{mg} / \mathrm{m}^{3}$.

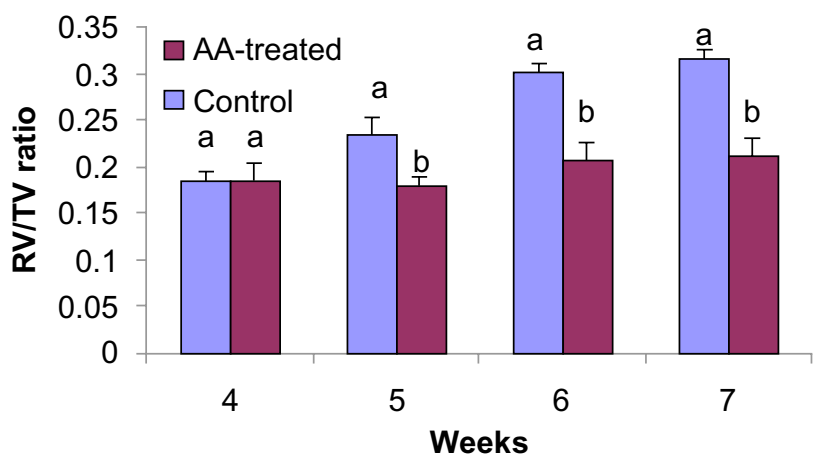

Figure 3 Overall mean effect of ascorbic acid on the development of $\mathrm{PH}$ in broilers during the harmattan periods of 2010-2013.

Notes: The overall mean effect of AA on the development of $\mathrm{PH}$ in control $(n=75)$ and AA-treated $(n=75)$ broilers during the harmattan periods of 2010-20।3. Bars with different superscript letters differ significantly between control and AA-treated $(P<0.05)$.

Abbreviations: RV/TV, right ventricle weight to total ventricle weight; $A A$, ascorbic acid; $\mathrm{PH}$, pulmonary hypertension. 


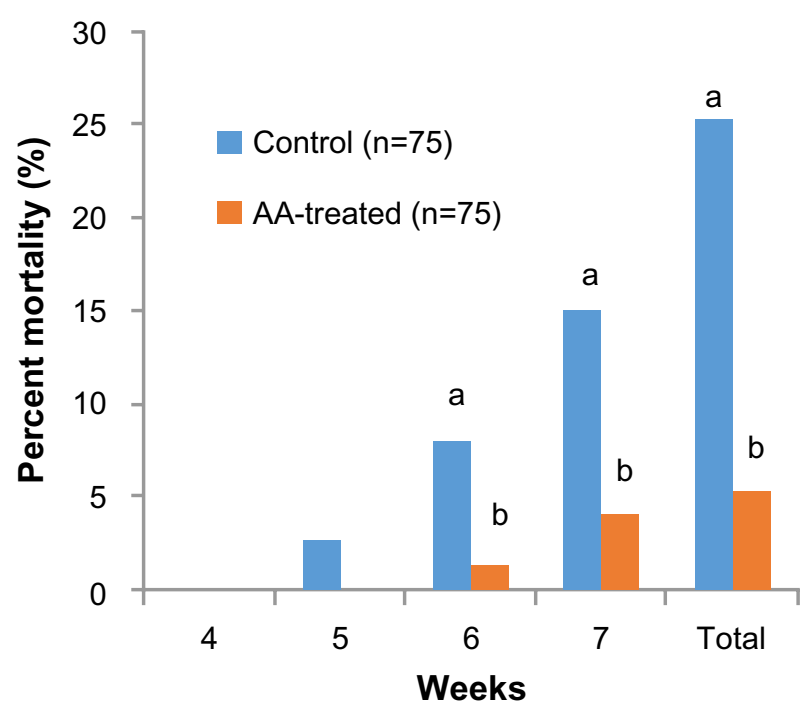

Figure 4 Effects of cold-dry (harmattan) season and the administration of ascorbic acid on mortality rate (\%) in broilers.

Note: Bars with different superscript letters differ significantly between control and AA-treated $(P<0.05)$.

Abbreviation: $\mathrm{AA}$, ascorbic acid.

\section{Blood parameters}

The PCV values, Hb concentrations, and RBC counts showed significant increase in control broilers from week 5 to 7 , as compared to those recorded in AA-treated broilers (Table 2). The PCV values were particularly significant $(P<0.001)$ in birds with higher $\mathrm{PH}$ index and abdominal fluid accumulation at weeks 6 and 7. The $\mathrm{Hb}$ index in control birds showed hypochromic RBCs.

\section{Discussion}

The harmattan periods were classic, characterized by a very cold-dry wind and a heavy dust-laden haze of extremely small dry particles suspended in the atmosphere. Therefore, the best prophylactic measures necessary to be taken against

Table 2 Effect of daytimes and nighttimes on colonic temperature $\left({ }^{\circ} \mathrm{C}\right)$ of broilers during weeks 4-7 of the study period

\begin{tabular}{|c|c|c|c|c|}
\hline \multirow[t]{2}{*}{ Weeks } & \multicolumn{2}{|l|}{ Daytime } & \multicolumn{2}{|l|}{ Nighttime } \\
\hline & $\begin{array}{l}\text { AA-treated } \\
(n=75)\end{array}$ & $\begin{array}{l}\text { Control } \\
(n=75)\end{array}$ & $\begin{array}{l}\text { AA-treated } \\
(n=75)\end{array}$ & $\begin{array}{l}\text { Control } \\
(n=75)\end{array}$ \\
\hline 4: $\mathrm{me}$ & $\begin{array}{l}41.7 \pm 0.1^{\mathrm{a}} \\
(41.2-42.2)\end{array}$ & $\begin{array}{l}41.4 \pm 0.3^{\mathrm{a}} \\
(40.4-42.4)\end{array}$ & $\begin{array}{l}40.4 \pm 0.2^{b} \\
(39.8-40.9)\end{array}$ & $\begin{array}{l}40.2 \pm 0.1^{\mathrm{b}} \\
(39.8-40.6)\end{array}$ \\
\hline 5: mean & $\begin{array}{l}41.4 \pm 0.3^{a} \\
(41.0-42.0)\end{array}$ & $\begin{array}{l}42.3 \pm 0.5^{\mathrm{b}} \\
(42.0-42.6)\end{array}$ & $\begin{array}{l}40.9 \pm 0.2^{\mathrm{b}} \\
(40.2-41.7)\end{array}$ & $\begin{array}{l}39.3 \pm 0.7^{c} \\
(38.8-39.8)\end{array}$ \\
\hline lean & $\begin{array}{l}42.0 \pm 0.4^{a} \\
(41.6-42.4)\end{array}$ & $\begin{array}{l}42.8 \pm 0.2^{b} \\
(42.5-43.1)\end{array}$ & $\begin{array}{l}41.5 \pm 0.5^{a} \\
(41.2-41.8)\end{array}$ & $\begin{array}{l}39.3 \pm 0.7^{c} \\
(38.6-40.1)\end{array}$ \\
\hline 7: mean & $\begin{array}{l}41.8 \pm 0.2^{\mathrm{a}} \\
(41.6-42.1)\end{array}$ & $\begin{array}{l}43.1 \pm 0.7^{\mathrm{b}} \\
(42.7-43.6)\end{array}$ & $\begin{array}{l}41.4 \pm 0.2^{\mathrm{a}} \\
(40.9-42.5)\end{array}$ & $\begin{array}{l}42.8 \pm 0.5^{b} \\
(42.4-43.2)\end{array}$ \\
\hline
\end{tabular}

Notes: Mean values with different superscript letters within a row differ significantly $(P<0.05)$ between control and AA-treated. Values in parenthesis are minimummaximum.

Abbreviation: AA, ascorbic acid. the adverse effects of the cold-dry and dust-laden wind was to optimize the thermal microenvironment and ventilation by insulating the poultry house. However, this practice is complex, expensive, and impractical under tropical harmattan conditions because of the wide fluctuation in AT between the daytime and nighttime. The thermal environmental variables recorded in the present study, especially during the nighttime, were outside the thermoneutral zone of $18^{\circ} \mathrm{C}-28.5^{\circ} \mathrm{C}$ for AT and $65 \%-70 \%$ for $\mathrm{RH}$, established for poultry in the tropical regions..$^{5,31,32}$ The thermal environmental data showed that the season, especially at night, was stressful and may not have favored optimum performance of the birds, and, consequently, profitable broiler production. This is because environmental stress factors associated with high or low AT have been reported to adversely affect the health, productivity, and welfare of birds. ${ }^{10,33}$ Furthermore, dust particles predispose birds to respiratory and cardiovascular diseases. ${ }^{34}$ Valentin et $\mathrm{al}^{33}$ observed that about $30 \%$ of broilers rejected at meat inspection showed lung lesions due to high concentrations of inhaled dust particles. The wide fluctuations in AT and $\mathrm{RH}$ between the daytime and nighttime time recorded in the present study posed a serious threat to the homeostasis of the birds. Wide and sharp variations in AT above the $20^{\circ} \mathrm{C}$ obtained in the present study have been reported to be stressful to poultry; these variations may also cause $\mathrm{PH}$ and death. ${ }^{35,36}$ It is important to note that in temperate countries, AT of $18^{\circ} \mathrm{C}$ is considered to be normal for matured poultry; however, in tropical countries such AT is just the lowest tolerable level. Thus, special consideration should be taken when explaining cold stress in the tropics.

The average $\mathrm{CT}$ values recorded in the broiler chickens were significantly different between birds; there were individual variations in the values of CT among birds of the same breed reared under the same conditions. In addition, the two-hourly variations in CT values may be due to circadian rhythm, classical of mammals and controlled by a biological clock in the hypothalamus. ${ }^{37}$ Similar fluctuations in CT of birds during the daytime during the harmattan and hot-dry periods have been reported by Ayo et $\mathrm{al}^{38}$ and Sinkalu and Ayo, ${ }^{7}$ respectively. The highest $\mathrm{CT}$ value of $43.1^{\circ} \mathrm{C}$ recorded during the afternoon hours in the control birds was higher than the established normal range values of $40^{\circ} \mathrm{C}-42^{\circ} \mathrm{C}$ for the poultry species. ${ }^{5}$ The result suggested that the birds may suffer moderate heat stress during the daytime, when the AT and $\mathrm{RH}$ values were also outside the thermoneutral zones. The result obtained in the present study was characteristic of the harmattan period, associated with high AT (up to $\left.31^{\circ} \mathrm{C}\right)$ during the daytime, but very low AT $\left(9^{\circ} \mathrm{C}-14^{\circ} \mathrm{C}\right)$ 
Table 3 Effect of harmattan season on some blood parameters of AA-treated $(n=40)$ and control $(n=40)$ broilers

\begin{tabular}{|c|c|c|c|c|c|c|c|c|}
\hline \multirow[t]{3}{*}{ Parameters } & \multicolumn{8}{|l|}{ Weeks } \\
\hline & \multicolumn{2}{|l|}{4} & \multicolumn{2}{|l|}{5} & \multicolumn{2}{|l|}{6} & \multicolumn{2}{|l|}{7} \\
\hline & AA & Control & AA & Control & AA & Control & AA & Control \\
\hline $\operatorname{RBC}\left(\times 10^{12} / \mathrm{L}\right)$ & $2.2 \pm 0.1^{\mathrm{a}}$ & $2.3 \pm 0.3^{a}$ & $2.5 \pm 0.2^{\mathrm{a}}$ & $2.8 \pm 0.5^{b}$ & $2.6 \pm 0.1^{a}$ & $3.0 \pm 0.3^{b}$ & $2.6 \pm 0.3^{a}$ & $3.8 \pm 0.5^{c}$ \\
\hline PCV (\%) & $31.5 \pm 2.2^{\mathrm{a}}$ & $31.3 \pm 3.1^{\mathrm{a}}$ & $34.9 \pm 1.5^{\mathrm{a}}$ & $38.7 \pm 1.5^{b}$ & $35.6 \pm 2.2^{\mathrm{a}}$ & $44.7 \pm 2.1^{c}$ & $36.0 \pm 1.5^{b}$ & $49.5 \pm 3.5^{c}$ \\
\hline $\mathrm{Hb}(\mathrm{g} / \mathrm{dL})$ & $8.5 \pm 0.1^{a}$ & $8.7 \pm 0.2^{\mathrm{a}}$ & $9.0 \pm 0.5^{\mathrm{a}}$ & $11.5 \pm 0.3^{\mathrm{a}}$ & $9.5 \pm 0.2^{\mathrm{a}}$ & $12.2 \pm 0.5^{b}$ & $9.8 \pm 0.4^{\mathrm{a}}$ & $13.6 \pm 0.5^{b}$ \\
\hline $\mathrm{Hb}$ index & $0.98^{a}$ & $0.99^{a}$ & $0.99^{a}$ & $0.85^{\mathrm{b}}$ & $0.98^{\mathrm{a}}$ & $0.88^{\mathrm{b}}$ & $0.98^{\mathrm{a}}$ & $0.80^{\mathrm{b}}$ \\
\hline
\end{tabular}

Note: Mean values with different superscript letters within a row differ significantly between control and $A A$-treated $(P<0.05)$.

Abbreviations: AA, ascorbic acid; RBC, erythrocyte; PCV, packed cell volume; Hb, hemoglobin.

during the nighttime and morning periods. ${ }^{15,38-41}$ The present result disagrees with the finding of Ayo et al,,$^{38}$ who showed no significant increase in RT values of Bovan Nera pullets during the harmattan season. The difference in the results may be due to high metabolic rates and the limited ability of broilers to exchange heat due to the broilers' weight and size when in the final stage of production. Thus, broiler chickens may be more vulnerable to thermal environmental changes, especially the concomitant effect of high and low AT values, compared to layer hens. In addition, the desiccating effect of the dusty and cold-dry wind acting on the birds may induce the secretion of corticosteroids - particularly cortisol, the chief hormone of stress - which may be responsible for the increase in $\mathrm{CT}$; this effect requires further investigation. The wide fluctuations in $\mathrm{CT}$ and $\mathrm{AT}$ observed in the present study between the daytime and nighttime periods confirm earlier reports that the harmattan season is the most thermally stressful of the three (harmattan, hot-dry, rainy) seasons in the Northern Guinea Savannah zone of Nigeria. ${ }^{4,15,38,41}$

The mean $\mathrm{CT}$ value of $39.3^{\circ} \mathrm{C} \pm 0.3^{\circ} \mathrm{C}$ recorded in the broiler chickens during the nighttime and early morning period at weeks 5 and 6 , when the AT and RH were far below the recommended lower limit values for poultry, suggests that the birds experienced cold stress. The result further demonstrates that at low AT (below $18^{\circ} \mathrm{C}$ ), the birds were unable to generate heat and thermoregulate efficiently; thus, the $\mathrm{CT}$ values decreased below the established normal values. This may have negative consequential effects on the health and productivity of the birds. Since cold stress reduces blood oxygen tension due to a decrease in flow of blood, the stress may perpetuate tissue hypoxia, consequently impairing the generation of adequate heat to maintain normal body temperature. Furthermore, low AT values were reported to suppress nutrient digestibility, decreasing the utilization of dry matter and crude protein. ${ }^{42}$ Therefore, low metabolism levels may be an additional reason why the control birds in the present study were unable to generate adequate heat to keep warm during the nighttime, when the AT was very low.
The result of the present study demonstrated for the first time the importance of assessment of CT during the nighttime, especially when the environmental conditions are at the low extreme levels. Such CT assessment may be of value in establishing the correct diagnosis during the daytime. The significantly higher CT values, well above normal for broilers, were recorded during both daytime and nighttime in control broilers that had obvious clinical signs of ascites; these values were evidenced by accumulated abdominal fluid at week 7 and demonstrated that measurement of CT at night may be employed to monitor the development of $\mathrm{PH}$ during the harmattan season. The result also demonstrated that the older the birds, the higher their chances of PH development, especially if the adverse effects of the thermal environment on the birds are protracted.

The present result showed that the development of $\mathrm{PH}$ in broilers during the harmattan season was first started by a significant decrease in CT during the nighttime (due to low AT) and, thereafter, by an increase in CT, apparently due to accumulation of abdominal and pericardial fluids. The initial increase in the CT values recorded in AA-treated broiler chickens during the morning and evening hours, 2 hours after the administration of $\mathrm{AA}$, was within the normal range of $40^{\circ} \mathrm{C}-42^{\circ} \mathrm{C}$ for broilers. The increase in $\mathrm{CT}$ value was higher $(P<0.05)$ in the AA-treated group than that in the control group, which demonstrated that the administration of AA induced CT elevation in the broilers subjected to cold conditions. This finding shows that AA exerts a biphasic effect on CT. First, it increases the CT whenever the value is at a lower limit threshold, as observed during the nighttime in AA-treated broilers in the present study. Second, it reduces CT values that are at the maximum threshold, as observed in the afternoon hours in the present study. The fact that the increase in $\mathrm{CT}$ values was recorded in AA-treated broilers during the daytime and nighttime was not different from normal range values suggested - for the first time - that AA alleviated the effects of daytime and nighttime cold-dry harmattan stress on the $\mathrm{CT}$ of broilers. 
The mechanism of action of AA on the cold stress factor was not investigated in the present study; however, it may be due to the inhibitory activity of AA as a vitaminergic neurotransmitter in the hypothalamus..$^{43}$ Apart from its antioxidant and thermoregulatory properties, AA is involved in thermoregulation by inhibiting cortisol, the chief hormone of stress. ${ }^{44}$ This is an important finding because cold stress has been implicated in the pathogenesis of $\mathrm{PH}$ and other related respiratory and cardiovascular diseases. ${ }^{26,45}$ The above normal CT values recorded in some control birds at the 7th week (during both the daytime nighttime), together with the fact that these birds had accumulated abdominal fluid, suggests that the broilers had fully developed ascites syndrome. Birds with ascites have been reported to have fluid accumulation in the abdomen and the pericardium. ${ }^{25,29}$

The mean RV/TV ratio of $0.178 \pm 0.05$ recorded in the brooded broilers at 4 weeks of age was below the recommended RV/TV ratio of $0.28,{ }^{25}$ this demonstrated that the brooded broilers did not develop any sign of $\mathrm{PH}$ at this age due to adequate provision of heat to maintain stable internal environment. However, after brooding from the 5 th to the 7th week, the RV/TV ratio obtained in the control birds was higher than the recommended values. Although there were no data on RV/TV ratio in broilers raised in the tropics during the harmattan season to warrant any comparison, the result of the present study, showed for the first time that the broilers raised during this period of the year in the tropics were subjected to environmental conditions that induced the development of PH. The factors that were responsible for the increase in RV/TV ratio in the present study were low AT, high levels of dust concentration, and wide fluctuations in AT. Cold temperatures increase the oxygen requirement, cardiac output, heart weight, and blood flow of the broiler chickens, probably as a result of the increased pulmonary arterial pressure, workload on both ventricles, and ultimately damage to the RV ${ }^{10,26}$ The observation that not all birds with significant increases in PH index, PCV, RBC count, and $\mathrm{Hb}$ concentration had clinical signs of ascites indicates that pathological changes in the heart and blood are not always predictive of ascites. This requires further investigation.

The significant increase in $\mathrm{RBC}$ count, $\mathrm{Hb}$ concentration, and PCV value in PH broilers may be due to a significant increase in the number of RBCs as a result of enhanced erythropoiesis, which also may contribute to a significant elevation in blood volume. The findings confirm an accelerated erythropoiesis in PH broilers. Increased RBC counts - through increased erythropoietin production, elevation of PCV value, and blood viscosity - have been reported in broilers suffering from $\mathrm{PH}^{29,46,47} \mathrm{The} \mathrm{Hb}$ index results in PH broilers suggests that individual RBCs had very low $\mathrm{Hb}$ content on their membranes, apparently due to increased proportion of immature RBCs in the circulation and enhanced erythropoiesis induced by oxygen deficiency due to cold stress. The result of the present study, for the first time, suggested that $\mathrm{Hb}$ index may be employed as one of the biomarkers of PH in broilers.

Dust control has been reported to be an important management challenge facing the broiler industry; the highest dust concentrations are found in poultry houses, followed by houses for keeping pigs and cattle. ${ }^{14}$ Although there are no recommended safe values on the amount of dust inhaled by poultry during the harmattan season, the desiccating effect of the high concentration of inhaled dust particles $\left(8.2 \pm 0.3 \mathrm{mg} / \mathrm{m}^{3}\right)$ recorded in the present study was above the normal recommended concentration value of $3.6 \mathrm{mg} / \mathrm{m}^{3}$ for poultry houses in temperate climates. ${ }^{48}$ The high dust concentration obtained in the present study may induce a sensitization within the lung tissue, irritate the mucous membranes, and cause a restriction in the bronchi, effects similar to those for an allergenic reaction. The response may reduce the efficiency of oxygen uptake by the lungs and overload the lung clearance mechanism of the broilers, consequently exacerbating the development of $\mathrm{PH}$. Although the concentration of dust particles recorded in the present study was not separated from that of the entire dust generated by the birds, feeds or litter, the harmattan dust obviously constituted the greatest portion of the entire dust. This is because the density of the birds in the pen was low and the wood shavings were kept clean. Harmattan dust particles in the zone are reported to be very high (Figure 1) and measure about $0.5-10 \mu \mathrm{m} .{ }^{3}$ Such tiny dust particles escape entrapment by the defense mechanisms of the respiratory system and may predispose the respiratory and cardiovascular systems of the broilers to many pathological changes. Similar effects of dust particles on the respiratory and cardiovascular systems and PH development have been reported in humans and animals. ${ }^{49,50}$ Furthermore, the tiny dust particles may penetrate materials used for dust prevention in the poultry house without compromising ventilation. Therefore, it becomes physically impossible to control the adverse effects of the harmattan dust on birds reared during the season; AA administration, based on its antioxidant properties or indirect mechanism of action, may protect the endothelium of the mucous membrane of upper respiratory tract of the birds from the adverse effects of dust particles. Consequently, AA administration may be of paramount significance. 
Furthermore, the wide fluctuations in AT recorded between daytime and nighttime during the harmattan season may exacerbate the induction of $\mathrm{PH}$. Such wide fluctuations in AT have been reported to be more stressful to birds than a steady AT; they often result in high mortality. ${ }^{5}$ Although moderate heat stress was observed in the afternoon hours, when the AT value was higher than the thermoneutral zone, this may not induce PH because the alternating effect of the heat was moderate and lasted only a few hours, between $1 \mathrm{pm}$ to $3 \mathrm{pm}$. The result of the study agreed with the findings of Kim et al,${ }^{51}$ who showed that the effect of alternating environmental AT between cold and heat is largely under cold stimulus, rather than hot. Thus, the protracted cold-dry (harmattan) effect recorded in the present study has taken precedence over the short period of heat stress observed in the afternoon hours of the day.

The RV/TV ratio of $0.315 \pm 0.04$ recorded at the 7 th week in the present study was similar to the result recorded by Zamani Moghaddam et $\mathrm{al}^{13}$ in broilers, raised under high altitude. The increase in the RV/TV ratio with increase in the age of the birds demonstrated that the older the birds, the higher the risk of $\mathrm{PH}$ development. This finding was apparently due to the persistence in the severity of the harmattan wind and the high concentration of dust throughout the study period. It is still not clear whether the changes recorded in heart morphology were adaptive and reversible, as they occurred during the development of hypoxic $\mathrm{PH} .{ }^{6,47}$ This may require further investigation.

In birds administered with AA, the RV/TV ratios recorded at the 5th, 6th, and 7th week were significantly $(P<0.05)$ lower than that obtained in control birds and were not above the normal ratio of 0.28 . The result demonstrated that AA ameliorated the negative effects of cold-dry (harmattan) stress on the development of PH. Furthermore, the result suggested that broilers that developed PH had low levels of AA. The result is in agreement with the findings of Cheng et $\mathrm{al}^{52}$ and Xiang et al, ${ }^{8}$ who showed that AA synthesis was insufficient during cold exposure and that the level of antioxidants in ascitic broilers decreased considerably, compared to that in healthy broilers.

The mechanism of action of AA in mitigating PH may be through detoxification of reactive oxygen species (ROS), apparently generated in large quantity during the harmattan season. Factors favoring the increased ROS production may include high demand for cellular oxygen due to low AT and $\mathrm{RH}$ that occurred during the season, especially during the nighttime, and the concomitant effect of high quantities of inhaled dust particles. AA has been shown to be a powerful antioxidant, scavenging ROS, including free radicals, by donating a hydrogen molecule. AA also reduces thermal load in birds subjected to extreme environmental conditions, ${ }^{20,44}$ like those seen in the present study. The result further suggested that AA played a significant role in enhancing the functions of the respiratory tract and cardiac endothelium; thus, the broilers administered with AA had lower RV/TV ratios and were able to withstand the adverse effects of inhaled dust particles. The present findings support those of Balz ${ }^{44}$ and Korantzopoulos and Galaris, ${ }^{53}$ who showed that AA is beneficial during cold stress, and in patients with cardiovascular problems. Similar beneficial effects of antioxidant vitamins $\mathrm{C}$ and $\mathrm{E}$, and selenium, against the development of $\mathrm{PH}$ have been reported in broilers in temperate regions of the world. ${ }^{8,13,54}$ Abo-Elouun and Al-Humiany ${ }^{55}$ demonstrated that the mechanism of action of AA in alleviating PH was due to the ability of AA to reduce blood flow resistance, especially in the narrow capillaries of the lungs. The result supports the finding of the present study that AA also mitigated the induction of PH due to harmattan stress and high level of inhaled dust particles.

The high mortality recorded in control birds and the results of the postmortems confirmed that the birds died as a result of ascites syndrome, apparently induced by improper thermoregulation, hypoxia, wide fluctuations in AT, and high concentrations of dust particles. Although the physical, chemical, and biological compositions of the dust particles were not investigated in the present study, it may be possible that some dust-associated pathogens were responsible for the mortality recorded. Further study is required in this direction. The low mortality rate of 5.3\% recorded in AA-treated broilers and the lack of any $\mathrm{PH}$ lesion postmortem suggests that AA, through the different mechanisms described earlier, prevented the development of $\mathrm{PH}$ and improved the health and viability of the birds reared under the stressful harmattan conditions.

Although cold exposure is reported to increase feed intake, it also reduces productivity. ${ }^{36,56}$ The liveweight of the control birds in the present study was lower than that recorded in AA-treated birds, which indicates the adverse effect of the harmattan stress on the liveweight of broilers. The negative effect was apparently induced because a substantial amount of the feed consumed by control broilers were utilized for the maintenance of homeostasis, rather than for weight gain. Additionally, hypoxia, which is associated with cold exposure (a condition in the present study) has been reported to inhibit gut development and poor growth rate in broilers; this is due to the high demand for oxygen by gastrointestinal organs..$^{57,58}$ 
Furthermore, the high levels of dust particles obtained in the present study have been reported to reduce growth and feed efficiency in poultry. ${ }^{48}$ Thus, the increased liveweight recorded in AA-treated broilers compared to the control group suggests that AA enhanced the mechanism of thermoregulation. Consequently, the larger part of the feed consumed by AA-treated birds was apparently utilized for body weight gain, rather than for thermoregulation. In addition, AA has been reported to improve nutrient absorption in the intestine and the release of digestive enzymes by the pancreas, ${ }^{13}$ and these functions may lead to increased feed utilization and liveweight gain in AA-treated broilers in the present study. Similar beneficial effects of AA supplementation on growth rate of chickens have been reported elsewhere. ${ }^{59}$

Overall, the result of the present study suggested that the majority of broilers reared to maturity during the harmattan season - although they show no obvious manifestations of clinical ascites syndrome - may develop PH syndrome which compromises meat quality and reduces the economic value of the broilers. This may require further investigation.

\section{Conclusion}

In conclusion, broiler chickens reared during the harmattan season developed PH due to the adverse effects of the cold-dry wind, wide fluctuations in AT during the daytime and nighttime, and high dust concentration, the effects of which were ameliorated by AA administration. The administration of AA may enhance the welfare, health, productivity, and meat quality of broiler chickens raised during the harmattan season.

\section{Disclosure}

The authors report no conflicts of interest in this work.

\section{References}

1. Rosenberg J, Burt PJA. Windborne displacement of desert locusts from Africa to the Caribbean and South America. Aerobiology. 1999;15: $167-175$.

2. Griffin DW, Garrison VH, Herman JR, Shinn EA. African desert dust in the Caribbean atmosphere: microbiology and public health. Aerobiology. 2001;17:203-213.

3. Oladele AO. Harmattan haze and environmental health. Afr J Environ Sci Technol. 2007;1(4):1-3.

4. Ayo JO, Owoyele OO, Dzenda T. Effects of ascorbic acid on diurnal variations in rectal temperature: of Brown Nera pullets during the harmattan season. Inter J Poult Sci. 2007;6(8):612-616.

5. Donkoh A. Ambient Temperature: a factor affecting performance and physiological response of broiler chickens. Inter J Biometeorol. 1989;33(4):259-265.

6. Jena BP, Panda N, Patra RC, Mishra PK, Behura NC, Panigrahi B. Supplementation of vitamin $\mathrm{E}$ and $\mathrm{C}$ reduces oxidative stress in broilers breeders hens during summer. Food Nutr Sci. 2013;4(8A):33-37.

7. Sinkalu VO, Ayo JO. Modulating role of vitamin A on individual and diurnal fluctuations in rectal temperature of Black Harco pullets. Inter J Appl Res Vet Med. 2009;7:102-111.
8. Xiang RP, Sun WD, Wang JY, Wang XL. Effect of vitamin C on pulmonary hypertension and muscularization of pulmonary arterioles in broiler. Br Poult Sci. 2002;43:705-712.

9. Balog JM. Ascites syndrome (Pulmonary hypertension syndrome) in broiler chickens: are we seeing the light at the end of the tunnel? Avian Poult Biol Rev. 2003;14(3):99-126.

10. Pakdel A, Van Arendonk Jam, Vereijken Alj, Bovenhuis H. Genetic parameters of ascites-related traits in broilers: effect of cold and normal temperature conditions. Br Poult Sci. 2005;46(1):35-42.

11. Julian RJ. The response of the heart and pulmonary arteries to hypoxia, pressure, and volume. A short review. Poult Sci. 2007;86(5):1006-1011.

12. Lorenzoni AG, Widema RF Jr. Intratracheal administration of bacterial lipopolysaccharide elicits pulmonary hypertension in broilers with primed airways. Poult Sci. 2008;87(4):645-654.

13. Zamani Moghaddam AK, Hassanpour H, Mokhtari A. Oral supplementation with vitamin $\mathrm{C}$ improves intestinal mucosa morphology in the pulmonary hypertensive broiler chicken. Br Poult Sci. 2009; 50(2):175-180.

14. Lai HT, Nieuwland MG, Kemp B, Aarnink AJ, Parmentier HK. Effects of dust and airborne dust components on antibody responses, body weight gain, and heart morphology of broilers. Poult Sci. 2009;88(9): 1838-1849.

15. Ayo JO, Minka NS. Influence of harmattan day and nighttime on rectal temperature fluctuations of broiler chickens. In: Proceedings of the International Conference of Nigerian Meteorological Society; November 13-17, 2011; Ahmadu Bello University, Zaria Nigeria.

16. Aftab U, Khan AA. Strategies to alleviate the incidence of ascites in broilers: a review. Braz J Poult Sci. 2005;7(4):199-204.

17. Singh PK, Pallav S, Kaushal K. Nutritional and managemental control of ascites syndrome in poultry. Inter J Livest Prod. 2011;2(8):117-123.

18. National Research Council (NRC). Nutrition Requirements of Poultry. 9th ed. Washington, DC: Nat Acad Sci; 1994.

19. Manjula KR, Subramanyam MV, Asha Devi S. Protection against oxidative stress caused by intermittent cold exposure by combined supplementation with vitamin $\mathrm{E}$ and $\mathrm{C}$ in the aging rat hypothalamus. Neurochem Res. 2013;38(4):876-885.

20. Minka NS, Ayo JO. Behavioural and rectal temperature responses of Black Harco pullets administered vitamin $\mathrm{C}$ and $\mathrm{E}$ and transported by road during the hot-dry season. J Vet Behav: Clin Res Appl. 2010;5(3): 134-144.

21. Smirnov AM, Konopelko PY, Pushkov SP, et al. Methods of clinical examination. In: Smirnov AM, editor. Internal Non-infectious Diseases of Animals. Moscow, Russia: Kolos Press; 1987:11-21. Russian.

22. Schalm OW, Jain N, Carroll EJ. Veterinary Haematology. 3rd ed. Philadelphia: Lea and Freiberg; 1975.

23. Luger D, Shinder D, Wolfenson D, Yahav S. Erythropoiesis regulation during the development of ascites syndrome in broiler chickens: A possible role of corticosterone. J Anim Sci. 2003;81(3):784-790.

24. Minka NS, Ayo JO. Physiological responses of erythrocytes of goats to transportation and the mondulatory role of ascorbic acid. $J$ Vet Med Sci. 2010;72(7):875-881.

25. Wideman RF. Pathophysiology of heart/lung disorders pulmonary hypertension syndrome in broiler chickens. World's Poult Sci. 2001;57(3):289-305.

26. Julian RJ, McMillan I, Quinton M. The effect of cold and dietary energy on right ventricular hypertrophy, right ventricular failure and ascites in meat-type chickens. Avian Pathol. 1989;18(4):730-732.

27. Cawthorn D, Beers K, Bottje WG. Electron transport chain defect and inefficient respiration may underlie pulmonary hypertension syndrome (ascites)-associated mitochondrial dysfunction in broilers. Poult Sci. 2001;80(4):474-484.

28. Zhou DH, Wu J, Yang SJ, Cheng DC, Guo DZ. Intravenous endothelin-1 triggers pulmonary hypertension syndrome (ascites) in broilers. Vet Med (Praha). 2008;53(7):381-391.

29. Wideman RF, Rhoads DD, Erf GF, Anthony NB. Pulmonary arterial hypertension (ascites syndrome) in broilers: a review. Poult Sci. 2013;92(1):64-83. 
30. Vucemilo M, Matkovic K, Vinkovic B, et al. Effect of microclimate on the airborne dust and endotoxin concentration in a broiler house. Czech J Anim Sci. 2008;53(2):83-89.

31. Macari M, Furlan RL. Environmental Science on Poultry Production under Tropical Climate. In: Silva IJO, editor. Environmental Science on Poultry Production under Tropical Climate. Pivacicaba: FUNEP. 2001;1:146-164.

32. Oluyemi JA, Roberts FA. Poultry Production in Warm Wet Climates. 2nd ed. Londong: The Macmillan Press; 1979.

33. Valentin A, Bergmann V, Scheer J, Tschirch I, Leps H. Tierverluste und Qualitätminderungen durch Hauterkrankungen bei Schlachtgeflügel. Monatshefte [Dead losses and losses of meat quality by skin diseases in broilers]. Vet Med. 1988;43:686-690.

34. Chang CW, Chung H, Huang CF, Su HJ. Exposure of workers to airborne microorganisms in open-air swine houses. Appl Env Microbiol. 2001;67(1):155-161.

35. Yardimci M, Sengor E, Sahin EH, Bayram I, Cetingul IS. The Influence of Cold Conditioning on the Performance of the Broiler Chicken. Turk J Vet Sci. 2006;30:583-588.

36. Lorenzoni AG, Ruiz-Feria CA. Effects of vitamin E and 1-arginine on cardiopulmonary function and ascites parameters in broiler chickens reared under sub-normal temperatures. Poult Sci. 2006;85(12):2241-2250.

37. Piccione G, Caola G. Biological rhythm in livestock. J Vet Sci. 2002;3(3):145-157.

38. Ayo JO, Oladele SB, Fayomi A, Jumbo SD, Hambolu JO. Body temperature, respiration and heart rate in the Red Sokoto goat during the harmattan season. Bull Anim Hlth Prod Afr. 1998;46:161-166.

39. Igono MO, Molokwu ECI, Aliu YO. Body temperature responses of Savannah Brown goats to the harmattan and hot-dry season. Inter $J$ Biometeorol. 1982;26(3):225-230.

40. Igono MO, Molokwu ECI, Aliu YO. Seasonal variation in rectal temperature of Yankasa sheep. Vet Res Comm. 1983;6(3):223-226.

41. Dzenda T, Ayo JO, Lakpini CAM, Adelaiye AB. Seasonal, sex and live weight variations in feed and water consumption of Adult captive African giant rats (Cricetomys gambianus, Waterhouse-1840) kept individually in cages. J Anim Physiol Anim Nutr(Berl). 2013;97(3): 465-474.

42. Sahin N, Sahin K. Optimal dietary concentrations of vitamin C and chromium picolinate for alleviating the effect of low ambient temperature $\left(6.2^{\circ} \mathrm{C}\right)$ on egg production, some egg characteristics, and nutrient digestibility in laying hens. Vet Med - Czech. 2001;46(9-10):229-236.

43. Karanth S, Yu WH, Walczewska A, Mastronardi C, McCann SM. Ascorbic acid acts as an inhibitory transmitter in the hypothalamus to inhibit stimulated luteining hormone-releasing hormone release by scavenging nitric oxide. Proc Nat Acad Sci U S A. 2000;97(4):1891-1896.
44. Balz F. Vitamin C intake. Nutr Dis. 2003;14:1-8.

45. Ipek A, Sahan U. Effects of cold stress on broiler performance and ascites susceptibility. Asian-Aust J Anim Sci. 2006;19(5):734-738.

46. Franciosini MP, Tacconi G, Leonardi L. Ascites syndrome in broiler chickens. Vet Sci Res. 2012;3(1):60-66.

47. Wang Z, Chesler NC. Pulmonary vascular mechanics: important contributors to the increased right ventricular after-load of pulmonary hypertension. Exp Physiol. 2013;98(8):1267-1273.

48. Takai H, Pedersen JS, Johnsen JO, et al. Concentrations and emissions of airborne dust in livestock buildings in northern Europe. J Agric Eng Res. 1998;70(1):59-77.

49. World Health Organization. Air Quality Guidelines for Europe. 2nd ed. Geneva: WHO Regional Publications; 2000.

50. Kirychuk SP, Dosman JA, Reynolds SJ, et al. Total dust and endotoxin in poultry operations: Comparison between cage and floor housing. J Occup Env Med. 2006;48(7):741-748.

51. Kim YS, Kim WJ, Kim HK, Hong SS. Effect of hot and cold environments on the exocrine pancreas of rats. Yonsei Med J. 1970;11(1): $1-9$.

52. Cheng TK, Coon CN, Hamre ML. Effect of environmental stress on the ascorbic acid requirement of laying hens. Poult Sci. 1990;69(5): 774-780.

53. Korantzopoulos P, Galaris D. The protective role of Vitamin C on endothelial dysfunction. J Clin Basic Cardiol. 2003;6(1-4):3-6.

54. Roch G, Boulianne M, De Roth L. Effect of dietary antioxidants on the incidence of pulmonary hypertension syndrome in broilers [webpage on the internet]. Montreal; University of Montreal: 2007. Available from: http://en.engormix.com/MA-poultry-industry/articles/effect-dietaryantioxidants-incidence-t383/p0.htm. Date accessed: April 12, 2009.

55. Abo-Elouun SA, Al-Humiany AA. The prophylactic effects of vitamin C supplementation on sodium chloride-induced pulmonary hypertension in broiler chickens. Egyp Poult Sci J. 2011;31:15-20.

56. Stillman MJ, Shukitt-Hale B, Levy A, Lieberman HR. Spatial memory under acute cold and restraint stress. Physiol Behav. 1998;64(5): 605-609.

57. Yen JT, Nienaber JA, Hili DA, Pond WG. Oxygen consumption by portal vein-drained organs and by whole animal in conscious growing swine. Proc Soc Exp Biol Med. 1989;190(4):393-398.

58. de los Santos SF, Tellez G, Farnell MB, et al. Hypobaric hypoxia in ascites resistant and susceptible broiler genetic lines influence gut morphology. Poult Sci. 2005;84(9):1495-1498.

59. Seven PT, Seven I. Effects of selenium and vitamin c supplemented with high energy diet on the performance of broilers in cold $\left(15^{\circ} \mathrm{C}\right)$ environment. Bulg J Vet Med. 2009;12(1):25-32.

Open Access Animal Physiology

\section{Publish your work in this journal}

Open Access Animal Physiology is an international, peer-reviewed, open access journal publishing original research, reports, reviews and commentaries on all areas of animal physiology. The manuscript management system is completely online and includes a very

\section{Dovepress}

quick and fair peer-review system. Visit http://www.dovepress.com/ testimonials.php to read real quotes from published authors. 